\title{
Imaging in COVID-19-related myocardial injury
}

\author{
Riccardo Cau ${ }^{1} \cdot$ Pier Paolo Bassareo $^{2} \cdot$ Lorenzo Mannelli $^{3} \cdot$ Jasjit S. Suri $^{4} \cdot$ Luca Saba $^{1}$ (i)
}

Received: 11 June 2020 / Accepted: 26 October 2020 / Published online: 19 November 2020

(c) The Author(s) 2020

\begin{abstract}
Severe acute respiratory syndrome coronavirus 2 (SARS- CoV-2), previously named "2019 novel coronavirus" (2019-nCoV) is an emerging disease and a major public health issue. At the moment, little is known, except that its spread is on a steady upward trend. That is the reason why it was declared pandemic since March 11th, 2020. Respiratory symptoms dominate the clinical manifestations of the virus, but in a few patients also other organs are involved, such as their heart. This review article provides an overview of the existing literature regarding imaging of heart injury during COVID-19 acute infection and follow-up.
\end{abstract}

Keywords COVID-19 · Imaging · CMR · Myocarditis · Heart injury

Abbreviations
SARS- CoV-2
2019-nCoV
SARS
MERS-CoV
CK
CKMB
cTnI
HBDB
LDH
EBM
ESC
CMR
NT-proBNP
IL-6
FM

Luca Saba

lucasaba@tiscali.it

1 Department of Radiology, Azienda Ospedaliero Universitaria (A.O.U.), di Cagliari - Polo di Monserrato s.s. 554 Monserrato, 09045 Cagliari, Italy

2 Mater Misericordiae University Hospital and Our Lady's Children's Hospital, University College of Dublin, Crumlin, Dublin, Republic of Ireland

3 IRCSS SDN, Naples, Italy

4 Stroke Monitoring and Diagnostic Division, ATHEROPOINT LLC, Roseville, CA, USA
99mTc-MIBI SPECT Technetium-99m-labelled methoxyisobutyl isonitrile SPECT CCT Cardiac computed tomography LGE Late gadolinium enhancement

\section{Background}

In December 2019, different pneumonia cases of unknown aetiology presenting with severe acute respiratory syndrome (SARS), occurred in Wuhan, Hubei Province, China $[1,2]$. Since then, the disease has been spreading quickly from Wuhan to other geographical areas and countries. As to September 22th, 2020, 2,923,580 COVID cases in Europe were confirmed [3]. The SARS- CoV-2 has features which are typical of the coronavirus family. SARSCoV-2 shares $82 \%$ genome sequence similarity to SARS$\mathrm{CoV}$ and $50 \%$ genome sequence homology to Middle East respiratory syndrome coronavirus (MERS-CoV) [4]. Coronaviruses are quite common human pathogens, causing from mild acute respiratory disease (the common cold) to severe and potentially lethal respiratory tract infections [5]. A large number of reports provide descriptions of the clinical signs associated with COVID-19. Sun et al. observed that the most represented symptoms are fever and cough [6]. It is well known that different types of viruses, such as adenovirus, enterovirus and herpesvirus, but also coronavirus, may cause heart injury [7]; Alhogbani et al. reported that the MERS-CoV can cause acute myocarditis and heart failure [8]. Moreover, some patients with 
SARS may present with a transient increase in myocardial enzymes [9]. In previous report from China the prevalence of myocardial injury in COVID-19 was estimated to range between 23 and $28 \%$ [10, 11].

The incidence of cardiovascular complication remains unknown. Long et al. reported cardiovascular complications in the setting of COVID-19 pandemic [12]. In their report observed that myocardial injuries may occur in $7-31 \%$ patients, and around $7 \%$ of COVID related deaths were caused by myocarditis. Other cardiac complications observed were heart failure (23\%) and arrhythmias (7\%), while the incidence of acute coronary syndrome in COVID19 patient is still unclear $[12,13]$. This might be related to a marked reduction in percutaneous coronary artery interventions during COVID-19 pandemic, caused by lockdown effect [13]. Moreover, similarly to other viral illness, COVID-19 can trigger acute myocardial infarction and This might be due plaque rupture, coronary spasm or hypercoagulability with development of microthrombi $[12,13]$.

A challenge in coronavirus disease is represented by the occurrence of comorbidities, which may complicate patients' outcomes. According to Wang et al. hypertension, diabetes, and cardiovascular diseases were the most common coexisting conditions. Furthermore, patients with underlying comorbidities were admitted to ICU and showed more signs of cerebrovascular accidents in comparison with patients who were non-comorbid [2].
The purpose of this review is to provide an overview of the existing literature regarding the imaging of heart injury during COVID-19 acute infection and follow-up.

\section{SARS-COV-2 and the cardiovascular system}

Several studies hypothesize a potential role of cardiac damage induced by this virus. This is particularly important because of the link between lung and heart function. Previous reports about COVID-19 showed a significant increase in cardiac lesion biomarkers, including Cardiac troponin I (cTnI), Creatine Kinase (CK), $\alpha$-hydroxybutyrate dehydrogenase (HBDB), Lactate Dehydrogenase (LDH), and NTproBNP [14-17] (Table 1). Taken together, these laboratory abnormalities suggest that SARS- CoV-2 infection may be related to a variable degree of myocardial injury. Not only, but the alterations are similar to those previously observed in patients with MERS-CoV [2].

A case series of 138 hospitalized patients with a COVIDpneumonia, all with pulmonary infiltrates on chest CT, showed that the most common complications among these patients included ARDS and arrhythmia in $20 \%$ and $17 \%$ respectively, as well as shock (9\%) and acute cardiac injury (7\%). Patients admitted to ICU were more likely to suffer from one of these complications than those treated in ward [2].

Table 1 Previous reports about myocardial necrosis marker in COVID-19 patients

\begin{tabular}{|c|c|c|c|c|}
\hline & $\begin{array}{l}\text { Patients with } \\
\text { SARS-CoV-2 } \\
\text { infection }\end{array}$ & Patients with abnormal cardiac biomarkers & $\begin{array}{l}\text { Cardiac } \\
\text { lesion bio- } \\
\text { markers }\end{array}$ & Notes \\
\hline Xu et al. [16] & 53 & 30 & $\begin{array}{l}\text { LDH } \\
\text { CK } \\
\text { Myo } \\
\text { TNT-HSST } \\
\text { NT-proBNP }\end{array}$ & $\begin{array}{l}\text { This study shows that cardiac abnormalities } \\
\text { including elevated myocardial enzyme } \\
\text { levels (56.6\%) are common in COVID-19 } \\
\text { patients }\end{array}$ \\
\hline Wu et al. [5] & 188 & $\begin{array}{l}\text { Abnormal hs-TNI } 11.2 \% \\
68.6 \% \text { LDH abnormal } \\
76.1 \% \alpha \text {-HBDH abnormal } \\
\text { Abnormal CK } 11.2 \% \\
\text { Abnormal CK-MB } 10.1 \%\end{array}$ & $\begin{array}{l}\text { hs-TNI } \\
\text { CK } \\
\text { CK-MB } \\
\text { LDH } \\
\alpha-H B D H\end{array}$ & $\begin{array}{l}\text { This study assessed the associations } \\
\text { between heart injury indicators and mor- } \\
\text { tality in COVID-19 patients and that high } \\
\text { hs-TnI on admission can be associated } \\
\text { with higher mortality }\end{array}$ \\
\hline Bo Zhou et al. [26] & 34 & $\begin{array}{l}\text { Abnormal c-TNI } 8 / 8 \text { in very severe group } \\
\text { and } 1 / 26 \text { in severy group }\end{array}$ & $\begin{array}{l}\text { c-TNI } \\
\text { CK } \\
\text { LDH } \\
\alpha-H B D H\end{array}$ & $\begin{array}{l}\text { They found high percentage of increased } \\
\text { cTnI levels in very severe COVID-19 }\end{array}$ \\
\hline Huang et al. [15] & 41 & $\begin{array}{l}\text { Abnormal CK 13/40 (33\%) } \\
\text { Abnormal hs-TNI 5/41 (12\%) } \\
\text { Abnormal LDH 29/40 (73\%) }\end{array}$ & $\begin{array}{l}\text { LDH } \\
\text { CK } \\
\text { Hs-TNI }\end{array}$ & $\begin{array}{l}\text { They report a cohort of } 41 \text { patients with } \\
\text { laboratory confirmed 2019-nCoV infec- } \\
\text { tion }\end{array}$ \\
\hline Chen et al. [29] & 120 & $\begin{array}{l}\text { Abnormal c-TNI }(\mathrm{n}=12,10 \%) \\
\text { Abnormal NT-proBNP }(\mathrm{n}=33,27.5 \%)\end{array}$ & $\begin{array}{l}\text { NT-proBNP } \\
\text { c-TNI }\end{array}$ & $\begin{array}{l}\text { This study has shown condition of some } \\
\text { patients with severe SARS-CoV-2 infec- } \\
\text { tion, patients might deteriorate rapidly a } \\
\text { possible exitus was a fulminant myocar- } \\
\text { ditis }\end{array}$ \\
\hline
\end{tabular}


Shi et al. assessed the association between cardiac injuries and mortality in patients with COVID-19. They observed that patients with myocardial injuries were older, had more comorbidities, complications were more common, and mortality higher compared to those without cardiac damage. In addition, they reported that COVID-19 patients with preexisting cardiovascular diseases were more vulnerable to cardiac damage [14].

Nevertheless, there is still a lack of large multicentre studies and little evidence to establish a direct correlation between myocardial injuries and cardiovascular comorbidities.

COVID-19 could lead to cardiac injury indirectly (i.e. secondary to respiratory failure or to a harmful immune system response) or directly owing to viral replication in the myocardium, although the specific mechanism is still uncertain $[14,18]$.

In this respect, recently it was suggested that COVID19 may enter myocardial cells simply binding type 2 ACE receptors on their surface [19].

Varga et al. showed the presence of viral elements within endothelial cells, which also expresses ACE 2 receptors on their surface. This finding may explains the possible development of endothelitides, such as Kawasaki or Kawasakilike disease in children, as consequence of the virus entering the endothelial cells [20,21]. In addition, it might explain also the susceptibility to acute myocardial injury especially in patients with pre-existing endothelial disorders. Unfortunately, the available scientific evidence about histology in COVID-19 patients is poor. Also the drugs, which are administered as a therapy against COVID-19, may have potentially harmful cardiovascular side-effects and interactions with other medications [22, 23].

Current literature reports hypothesize that SARS-CoV2 infection could lead to cardiovascular complications or exacerbate a pre-existing cardiovascular disease [24-28]. At the beginning of 2020, a Chinese case report described for the first time a patient with COVID-19 and cardiac comorbidities who passed away because of a fulminant myocarditis (FM) [18].

In addition, another study by Chen et al. reported that some deaths in SARS-CoV-2-infected patients were associated with the sudden appearance of a myocarditis. In patients with an evident cardiac injury, plasma IL-6 levels were dramatically increased, since notoriously cytokine storm plays a pivotal role in FM pathophysiogy [29].

\section{Role of imaging}

Definitive COVID-19 diagnosis requires a positive reverse transcription-polymerase chain reaction test [30]. According to the current best medical practice suggestions, the diagnosis cannot be made by chest computed tomography; the latter, however, may be useful in assessing for a possible COVID-19 pneumonia, which usually is bilateral and with basal or multi-lobar distribution. Quickly progressive ground glass opacities, sometimes with consolidation, are the typical features. However, chest imaging has limited sensitivity for COVID-19, since up to $18 \%$ of the patients show normal chest-X ray or CT when their symptoms are mild, but this decreases to $3 \%$ in severe cases [31, 32].

As to cardiac involvement, non-invasive cardiac imaging during the pandemic might have an important role to decipher the rise in cardiac enzymes. In fact, the diagnosis of myocarditis remains still a challenge due to its variable clinical manifestations [33, 34] (Fig. 1).

The diagnostic gold standard for the diagnosis of myocarditis is endomyocardial biopsy (EMB) [35]. There are still no specific reports in literature about EMB in patients COVID-19 positive, except for a recent Chinese case report where a few interstitial mononuclear inflammatory infiltrates where described at a COVID-19 patient's heart specimen examination [36]. The histological findings in COVID-19 greatly resemble those previously seen in SARS and Middle Eastern respiratory syndrome (MERS) coronavirus infection [37, 38].

In a position statement from the European Society of Cardiology (ESC) Working Group on Myocardial and Pericardial Diseases, EMB is strongly recommended. It should be done early in the course of the disease and multiple specimens should be taken in order to optimize its diagnostic accuracy and reduce sampling error in focal myocarditis $[39,40]$. However, this procedure is infrequently used in clinical practice [35, 39-41].

The usual limitations of EMB in diagnosing myocarditis are represented by sampling errors caused by focal or patchy involvement of myocardium as well as high interobserver variability in interpreting histopathological tissue [42]. Due to this uncertainty, several non-invasive imaging modalities are helpful in diagnosing myocarditis (Table 2) [39, 43-46].

In the same ESC position paper, it is recommended that all patients with clinically suspected myocarditis should undergo an echocardiogram at disease presentation. It should be repeated during hospitalization if there is any worsening in haemodynamic [39]. Indeed, echocardiography is a safe, versatile, and widely available technique. It allows us to evaluate and quantify global and regional systolic function and monitor any possible changes in cardiac chambers size, wall thickness, ventricular function, and pericardial effusion $[39,47,48]$. Echocardiography is the first-line imaging modalities, but at the same its diagnostic value is limited owing to the lack of specificity of a lot of echocardiographic findings. In addition, patients with myocarditis may have a normal echocardiogram as well $[48,49]$. 


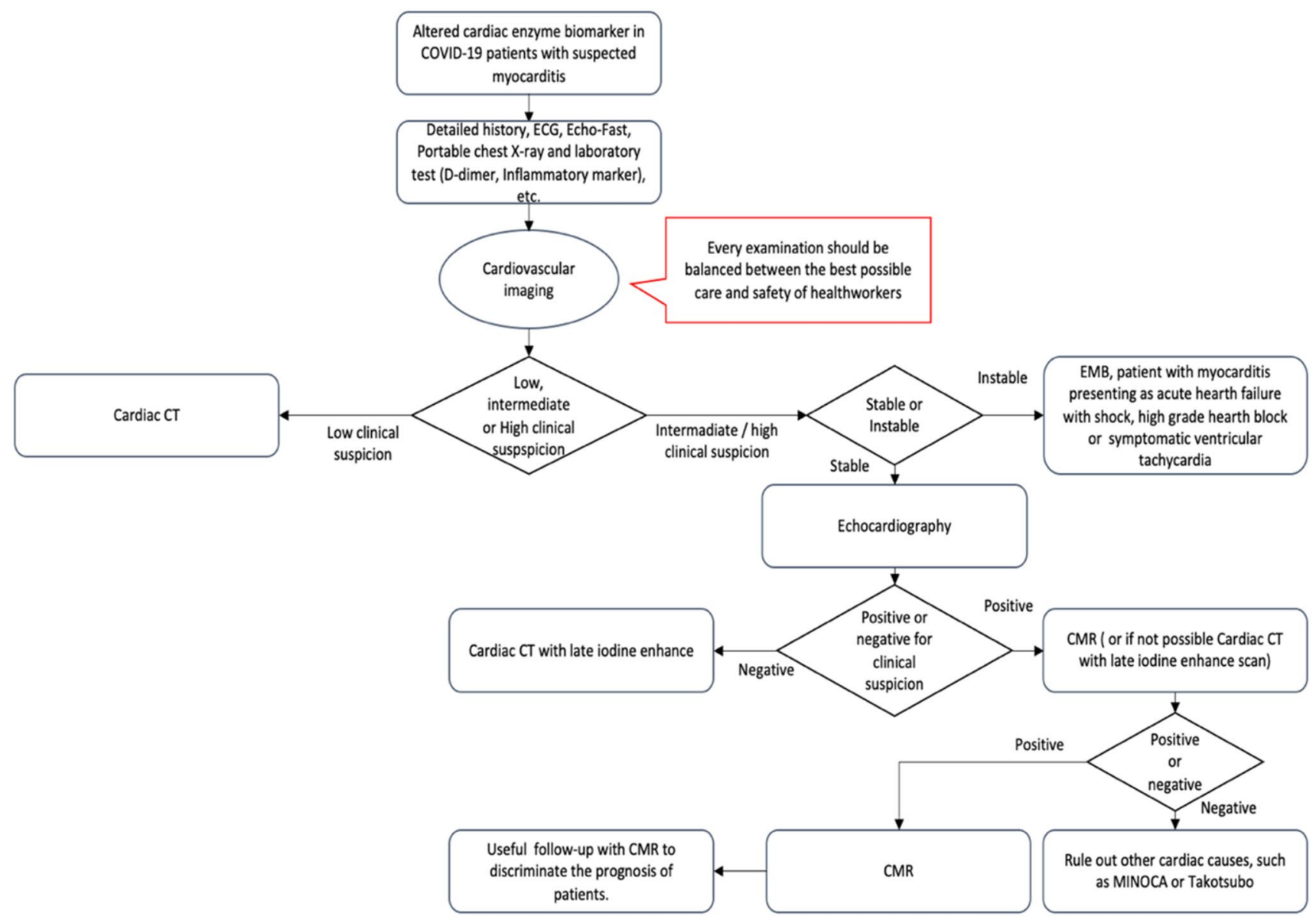

Fig. 1 Diagnostic pathway for suspected myocarditis

Echocardiography should not be performed routinely in patients with COVID-19, but bedside echocardiography could be a useful tool in clinical suspicion of myocardial involvement [45]. Moreover, the ventricular function can be evaluated in depth by using post- processing advanced echocardiography, such as myocardial strain. In patients with COVID-19 infection, Krishnamoorthy et al. reported that LV global longitudinal strain, RV global strain and free wall strain were altered. In addition, they observed that right ventricular strain may be important for risk stratification and prognosis as well. RV systolic dysfunction was more common than LV systolic dysfunction in COVID-19 patients. The etiology of this dysfunction could be related to pulmonary embolism, a common complication in this type of patients or to ARDS and its well-known sequelae, such as secondary pulmonary fibrosis $[50,51]$.

However, at present, there is still a lack of prospective study to assert with confidence the long- term pulmonary and cardiac consequences of COVID-19 [50, 51]. Echocardiographic myocardial strain is a time-consuming technique, a significant expertise is needed, and it is likely to be useful just in determining prognosis [45]. Other echocardiographic limitations include inadequate soft tissue characterization and suboptimal field-of-view in the setting of poor acoustic windows, such as in overweight/obese patients or in those suffering from SARS [52].

Conversely, nuclear imaging is not routinely recommended in the diagnosis of myocarditis [39, 42]. Sun et al. compared 99mTc-MIBI SPECT with other cardiac imaging techniques and assessed the presence of myocardial uptake of $99 \mathrm{mTc}-\mathrm{MIBI}$ as a marker of myocardial inflammation and necrosis [53]. Limitations of this technique include its reduced specificity, high cost, limited availability, and radiations exposure [39]. Nuclear cardiology imaging requires long imaging acquisition time and specific protocols. Therefore, other safer and faster cardiovascular tests should be more useful during the current pandemic [54].

According to Dambrin et al. in suspected acute myocarditis the findings from ECG-gated multidetector CT correlated significantly with those observed at MRI examination [55]. Other studies confirmed the potential role of cardiac computed tomography (CCT) in the setting of myocarditis [56-58]. Pontone et al. suggested the use of CCT -with pre-contrast, contrast-enhanced, and delayed post-contrast 
Table 2 Non-invasive imaging in the diagnosis of myocarditis

\begin{tabular}{|c|c|c|c|}
\hline Imaging modalities & Strengths & Limitations & $\begin{array}{l}\text { Reccomandation during COVID-19 } \\
\text { pandemic }\end{array}$ \\
\hline Echocardiography & $\begin{array}{l}\text { Safe } \\
\text { Versatile } \\
\text { Widely available technique } \\
\text { No radiation exposure or use of } \\
\text { contrast }\end{array}$ & $\begin{array}{l}\text { Inadequate soft tissue characteriza- } \\
\text { tion } \\
\text { Poor acoustic windows } \\
\text { Inter-observer variability } \\
\text { Highly variable echocardiographic } \\
\text { findings in myocarditis }\end{array}$ & $\begin{array}{l}\text { Bedside echocardiography should be } \\
\text { the first modalities in symptomatic } \\
\text { COVID-19 patients with altered } \\
\text { cardiac enzyme biomarker }\end{array}$ \\
\hline $\mathrm{CCT}$ & $\begin{array}{l}\text { High spatial resolution } \\
\text { Tissue characterization }\end{array}$ & $\begin{array}{l}\text { Radiation exposure } \\
\text { Contrast medium reactions }\end{array}$ & $\begin{array}{l}\text { Useful of CCT with late iodine } \\
\text { enhance scan }\end{array}$ \\
\hline CMR & $\begin{array}{l}\text { Tissue characterization } \\
\text { High spatial and temporal resolution } \\
\text { Excellent reproducibility } \\
\text { No radiation exposure }\end{array}$ & $\begin{array}{l}\text { Low availability } \\
\text { Costs } \\
\text { Intrinsic or extrinsic factors of the } \\
\text { patient (claustrophobia,metallic } \\
\text { implants, allergy, ability to hold } \\
\text { breath and arrhythmia) } \\
\text { Long scan times }\end{array}$ & $\begin{array}{l}\text { Main role in management of sus- } \\
\text { pected myocarditis to confirm the } \\
\text { diagnosis with fast CMR protocol }\end{array}$ \\
\hline Nuclear medicine techniques & $\begin{array}{l}\text { Marker of myocardial inflammation } \\
\text { and necrosis }\end{array}$ & $\begin{array}{l}\text { Limited specificity } \\
\text { Cost } \\
\text { Limited availability } \\
\text { Radiation exposure }\end{array}$ & Not useful \\
\hline Chest $\mathrm{X}$ ray & Indirect sign & $\begin{array}{l}\text { Low sensitivity } \\
\text { Very low specificity }\end{array}$ & $\begin{array}{l}\text { Portable x-ray should be the first line } \\
\text { modalities in asymptomatic and } \\
\text { minimally symptomatic COVID-19 } \\
\text { patients to have insight at the same } \\
\text { time about lung and heart }\end{array}$ \\
\hline
\end{tabular}

scans- as a tool to detect myocardial scar and diagnose myocarditis when c-MRI is not feasible [59].

Given the rise of cardiac enzyme biomarker, CCT may play a leading role in ruling out other causes of cardiac damage, such as acute coronary syndrome [60].

It also allows an evaluation of extracardiac structures that could explain an increase in troponin values (for example, pericarditis). In fact, it can be used to study lung and aortic structures and exclude lung complication in COVID-19 patient such as pulmonary embolism, or cardiac complication such as ventricular dilation and intracavitary thrombi $[10,61]$.

The main limitation of CCT is radiation exposure for the patient. Therefore, CCT is considered useful when performing an MRI scan is not possible because of contraindications to MRI or suboptimal images due to artifacts [52].

Another non-invasive modality which, however, may play just a marginal role is chest X-Ray. It does not allow the diagnosis of myocarditis, but may show indirect signs, as cardiomegaly and/or pericardial effusion with low sensitivity (71\%) and even less specificity $(41 \%)[62,63]$. The American College of Radiology suggested the use of portable chest radiography as optimal tool to mitigate the risk of infection [64]. Baldirani et al. proposed a possible role for chest X-ray just for asymptomatic or minimally symptomatic patient in epidemic regions [65]. Therefore, in the setting of COVID19 pandemic, (especially portable) chest X-ray might be the first line test in asymptomatic or with few symptoms patients to get information about lungs and heart dysfunction at the same time.

Cardiac magnetic resonance imaging (CMR), which provides non-invasive myocardial tissue characterization, is the gold standard imaging technique in diagnosing myocarditis [47]. Based on the Lake Louis criteria, CMR can identify myocardial damage with a diagnostic accuracy of $78 \%$. Lake Louise criteria include detection of regional edema on T2-weighted CMR images, detection of hyperemia and early capillary leakage on the basis of T1-weighted early gadolinium enhancement, and detection of necrosis and fibrosis by late gadolinium enhancement (LGE), with high specificity and positive predictive value when 2 out of 3 CMR characteristics are present [48].

Myocarditis-induced alterations may present with several patterns of LGE (Fig. 2), typically localized at the sub-epicardial and/or intramural regions of the left ventricle and frequently located in the basal to mid-inferolateral walls. Preliminary observation in the literature suggest that myocardial injuries might be related to other aetiologies than myocarditis. Guagliumi et al. suggested that patients with myocardial injuries and normal coronary artery might be caused by microvascular thrombosis in the absence of epicardial coronary obstruction [66]. Direct viral infection of the endothelial cell or vascular injuries caused by the virus might be explain impaired microcirculatory system 


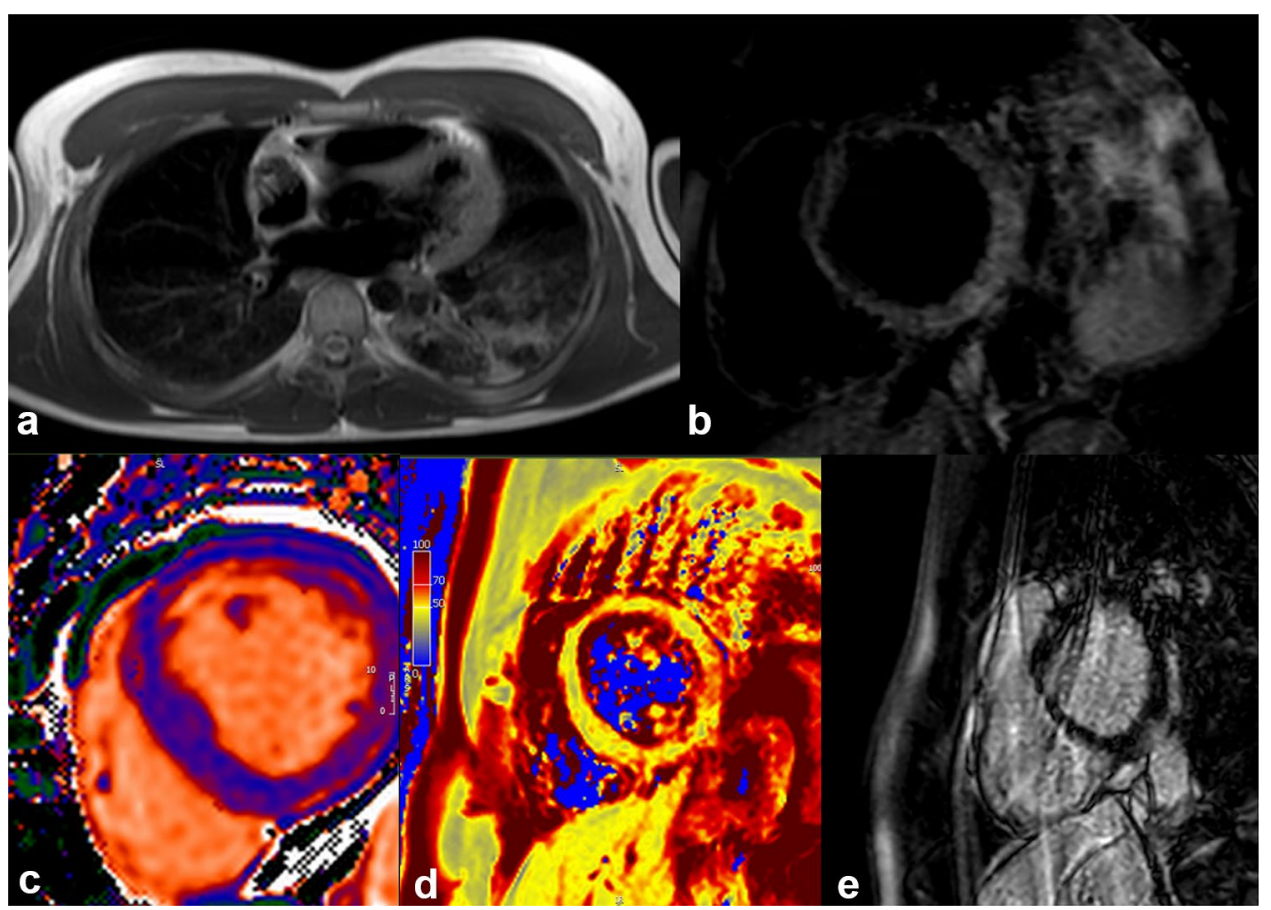

Fig. 2 A 27-year-old patient, without any significant past medical history, was admitted to our hospital with fever and chest pain. The onset of symptomatology dated back about 1 week. His initial investigation showed elevated troponin levels at laboratory tests. Electrocardiography displayed ST-segment elevation. Viral myocarditis of unknown aetiology was initially suspected, but SARS-Co-V-2 as a cause was ruled out later at serology. Echocardiography was normal. A chest $\mathrm{X}$-ray showed pulmonary consolidation at the left lower lobe. Cardiac magnetic resonance imaging confirmed the myocarditis (panel a). T2 STIR (panel b) showed an increased signal in mid-basal inferior and inferior-lateral segments. The analysis of T1 mapping (panel c) showed an increase in signal at the same segments (average values of $1100 \mathrm{~ms}$, with reference values of $1030 \pm 30 \mathrm{~ms}$ ). T2 mapping values (panel d) showed an increased signal in mid-basal inferolateral segment ( $65 \mathrm{~ms}$. Reference values: $52 \pm 3 \mathrm{~ms}$ ), thus indicating the presence of edema. In the sequences acquired later after contrast, an area of sub-epicardial LGE in mid-basal inferior and infero-lateral segments was observed with a concomitant involvement of the adjacent pericardium (panel e). Images processed with Circle CVI 42 with a prothrombotic state $[12,13,20]$. A literature review by Maiese et al. described autopsy findings in COVID-19 death. They have highlighted that SARS-CoV-2 causes endothelial dysfunction in various district [67]. Acute myocardial injuries might be due thrombotic complication $[66,68]$. Therefore, the term myocarditis should be used with caution in COVID-19 patients with elevated troponin levels without a specific diagnostic test.

In this scenario, CMR features are crucial in making a differential diagnosis with myocardial infarction (subendocardial or trans-mural LGE distribution; regional wall motion abnormalities at SSFP sequencies vs global hypokinesia in myocarditis), takotsubo syndrome (diffuse myocardial wall oedema, without arterial territory distribution; transient mid-apical dyskinesis/akinesis; mild late gadolinium enhancement just in the areas of abnormal wall motion, and no LGE at follow-up after resolution), and
MINOCA (i.e. myocardial infarction without non-obstructive coronary arteries, which is characterized myocardial oedema in a coronary distribution pattern [69].

Additionally, LGE has proven prognostic value, because patients with areas of necrosis and fibrosis are at increased risk of adverse events [70], whereas LGE-negative patients have an excellent prognosis independently of their clinical symptoms [71]. CMR diagnostic accuracy could increase with the proposed updated Lake Louis criteria, which include parametric mapping techniques, such as T2 mapping, T1 mapping and ECV. Precisely, T2 mapping can identify acute myocardial edema and has several advantages compared with traditional T2-weighted imaging, among which higher signal-to-noise ratio and shorter breath-holds with fewer breathing motion artifacts. Again, native T1 is sensitive to intracellular and extracellular changes in free water content and its relaxation time increase during acute 

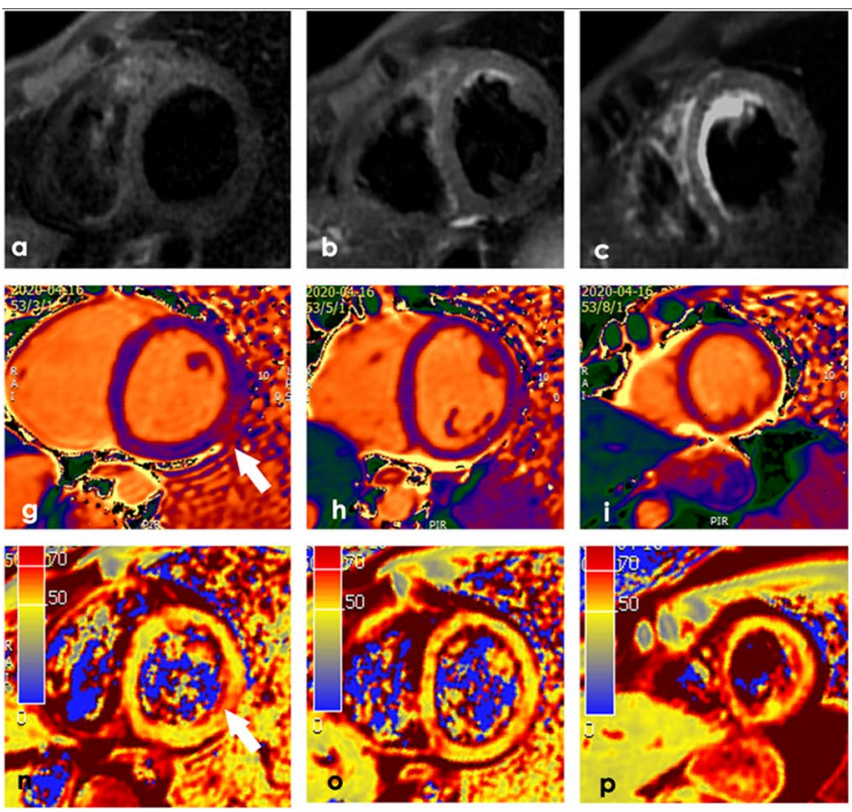

Fig. 3 A 37-year-old male patient, without any significant past medical history, was admitted to our hospital with oppressive chest pain, sweating, severe fatigue. At the swab was positive for COVID19. Sublingual nitroglycerin showed no clinical benefits with alterations in the LV Sax TIR T2 sequences $(\mathbf{a}-\mathbf{c})$ with patchy alterations in the LAx MDE sequences (d-f white arrows). Also the native T1 mapping

Table 3 CMR vs EMB

\begin{tabular}{|c|c|c|}
\hline & EMB & CMR \\
\hline Life-threatening presentations & + & - \\
\hline Clinically stable patients & - & + \\
\hline Arrhythmia & + & $(-)$ \\
\hline $\begin{array}{l}\text { Onset of the disease is longer than } \\
3 \text { months ago }\end{array}$ & + & - \\
\hline Follow-up & $\begin{array}{l}\text { Non-responsive } \\
\text { patients }\end{array}$ & + \\
\hline
\end{tabular}

inflammation, vasodilation, and hyperemia (Fig. 3). Lastly, ECV detects an expanded extracellular space and compared with LGE may assess diffuse fibrosis and inflammation [37, 72].

Adding these parametric mapping techniques to the classic CMR protocol may improve its accuracy, provide additional disease characterization, and help management in different cardiac injuries [72, 73]. A recent research by Puntmann et al. including 100 patients recovered from COVID19 infection, showed that native $\mathrm{T} 1$ and $\mathrm{T} 2$ mapping provide
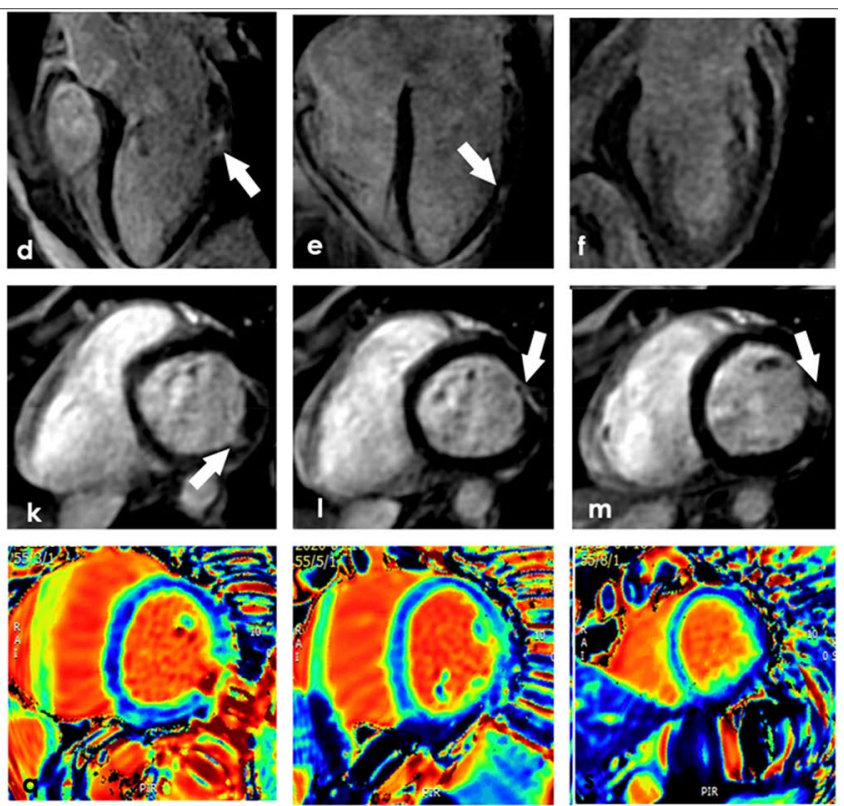

showed an area of alteration (white arrow) with areas of hypersignal in the SAx MDE sequences $(\mathbf{k}-\mathbf{m})$. The T2 map shows in the same region of the T1 map area of alteration (n-p white arrow). The $\mathbf{q}-\mathbf{s}$ panels show the ECV. Courtesy of Professor Gianluca Pontone MDCentro Cardiologico Monzino (Milano)

with the best differential parameters to detect COVID-19-related myocardial injuries [74] (Fig. 3).

CMR may be considered in clinically stable patients prior to EM [39]. Nonetheless, the latter should not be delayed in case of life-threatening presentations, because one of CMR limitations is that it is time-consuming, a long time being required for acquiring images (approximately $45 \mathrm{~min}$ with modern scanners) [39] (Table 3). A possible solution to reduce the examination time could be applying an ad hoc short protocol. So, Beitzke et al. proposed a fast CMR protocol, which incorporated reduced CINE sequences, parametric mapping, and LGE $[11,45]$. Furthermore, CMR may be an additional diagnostic tool in myocarditis clinical followup, when detecting persistent or worsening LGE [75].

LGE already proved to be one of the most important predictors of cardiovascular adverse outcomes in several cardiac conditions, myocarditis included $[70,76]$. Thereby, in COVID-19 patients with suspected myocardial damage, CMR is the only non-invasive imaging modality that allows tissue characterization, myocardial inflammation detection, and reversible/irreversible injury assessment, thus evaluating the myocarditis activity and severity. 
Table 4 Role of imaging in other less common COVID-19-related cardiovascular manifestations

\begin{tabular}{ll}
\hline Pulmonary embolism & CT angiogram with contrast (identification of intra pulmonary artery/branches/pulmonary vessels clots) \\
& Echocardiography (right ventricle secondary involvement) \\
Myocardial infarction & Echocardiography (ventricular wall motion abnormalities) \\
& Coronary angiogram (stenosis identification, blood flow evaluation) \\
& IVUS (intra-vascular ultrasounds for plaque visualization) \\
\hline
\end{tabular}

Currently, there is no evidence of possible long-term cardiac complications in COVID-19 patient, even though - as reported in recent research-an increased prevalence of arrhythmias and heart failure was detected [77-79].

CMR might play a leading role not only during the peak phase of the COVID-19 pandemic to decipher the cause of cardiac damage, but mostly afterwards, since it can reveal the presence of myocardial scar and consequent right and left ventricular remodeling that might influence the patient outcome [33, 51, 79].

Other possible, though less common, COVID-19 related cardiovascular manifestations are related to SARS-CoV-2 prothrombotic effects, with consequent risk of pulmonary embolism, myocardial infarction, and limb ischaemia [80]. Even in this setting cardiac imaging is proving its reliability (see Table 4). Collectively, SARS-CoV-2, cytokine release syndrome triggered by the viral antigen, drug-induced pulmonary toxicity, and high airway pressure secondary to mechanical ventilation cause secondary lung fibrosis in a considerable percentage of patients [81]. In the long-term, lung fibrosis is likely to cause the development of pulmonary hypertension and in turn cor pulmonale, i.e. a right sided heart failure. Even in this eventuality, cardiac imaging with echocardiography and CMR play a crucial role in providing valuable information about right ventricular mass, volume, kinesis, and function. By incorporating LGE, myocardial scar and fibrosis can also be evaluated by CMR.

\section{Conclusions}

It is well known that viral infections may involve the heart as well (Table 5), inducing myocardial inflammation [40, 77] or other cardiovascular complications [12, 13, 20, 66], testified by an increase in cardiac enzymes, as well as a structural and functional damage. A few studies confirm that also SARSCoV-2 can cause myocarditis and even congestive heart failure [21, 29, 65]. The higher the levels of cardiac enzymes and troponin, the higher the coronavirus mortality.

Although the specific mechanisms are still a matter of concerns, an abnormal immune system response is likely to be the underlying cause of myocardial injury during coronavirus infection. The pandemic spread of the virus, as testified by the number of infected subjects getting higher and higher as times goes by, suggests that potential cardiac involvement should be identified early in view of a prompt diagnosis capable of improving patients' outcome. In this respect, imaging - and in particular cardiac MRI with its most recent advanced toolsplays a crucial role. According to the International Guidelines, the involvement of a Heart Team made up of Radiologists and Cardiologists is critical in releasing a timely diagnosis, whose accuracy may help to save many lives threatened by such an aggressive disease.

Table 5 Viruses that can cause myocarditis

RNA virus Coxsackieviruses A and B, echoviruses, polioviruses, influenza A and B viruses, respiratory syncytial virus, Coronavirus, hepatitis $\mathrm{C}$ virus, dengue virus, yellow fever virus, human immunodeficiency virus-1

DNA virus DNA viruses: adenoviruses, parvovirus B19, cytomegalovirus, human herpes virus-6, Epstein-Barr virus, varicella-zoster virus, herpes simplex virus, variola virus, vaccinia virus 
Funding Open access funding provided by Università degli Studi di Cagliari within the CRUI-CARE Agreement.

\section{Compliance with ethical standards}

Conflict of interest The authors declare that they have no conflicts of interest.

Open Access This article is licensed under a Creative Commons Attribution 4.0 International License, which permits use, sharing, adaptation, distribution and reproduction in any medium or format, as long as you give appropriate credit to the original author(s) and the source, provide a link to the Creative Commons licence, and indicate if changes were made. The images or other third party material in this article are included in the article's Creative Commons licence, unless indicated otherwise in a credit line to the material. If material is not included in the article's Creative Commons licence and your intended use is not permitted by statutory regulation or exceeds the permitted use, you will need to obtain permission directly from the copyright holder. To view a copy of this licence, visit http://creativecommons.org/licenses/by/4.0/.

\section{References}

1. Lu H, Stratton CW, Tang YW (2020) Outbreak of pneumonia of unknown etiology in Wuhan, China: the mystery and the miracle. J Med Virol 92(4):401-402. https://doi.org/10.1002/jmv.25678

2. Wang D, Hu B, Hu C, Zhu F, Liu X, Zhang J, Wang B, Xiang H, Cheng Z, Xiong Y, Zhao Y, Li Y, Wang X, Peng Z (2020) Novel coronavirus-infected pneumonia in Wuhan, China. JAMA. https ://doi.org/10.1001/jama.2020.1585

3. ECDC: European Centre for Disease Prevention and Control; Situation update worldwide, as of 10 March 2020 08:00

4. Cascella M, Rajnik M, Cuomo A et al (2020) Features, evaluation and treatment coronavirus (COVID-19) [Updated 2020 Mar 20]. In: StatPearls [Internet]. Treasure Island (FL): StatPearls Publishing. https://www.ncbi.nlm.nih.gov/books/NBK554776/

5. Wu P, Hao X, Lau EHY, Wong JY, Leung KSM, Wu JT, Cowling BJ, Leung GM (2020) Real-time tentative assessment of the epidemiological characteristics of novel coronavirus infections in Wuhan, China, as at 22 January 2020. Euro Surveill 25(3). https ://doi.org/10.2807/1560-7917.ES.2020.25.3.2000044

6. Sun P, Qie S, Liu Z, Ren J, Li K, Xi J (2020) Clinical characteristics of hospitalized patients with SARS-CoV-2 infection: a single arm meta-analysis. J Med Virol. https://doi.org/10.1002/ jmv.25735

7. Pollack A, Kontorovich A, Fuster V et al (2015) Viral myocarditis-diagnosis, treatment options, and current controversies. Nat Rev Cardiol 12:670-680. https://doi.org/10.1038/nrcar dio. 2015.108

8. Alhogbani T (2016) Acute myocarditis associated with novel Middle east respiratory syndrome coronavirus. Ann Saudi Med 36(1):78-80. https://doi.org/10.5144/0256-4947.2016.78

9. Han Y, Geng H, Feng W, Tang X, Ou A, Lao Y, Xu Y, Lin H, Liu H, Li Y (2003) A follow-up study of 69 discharged SARS patients. J Tradit Chin Med 23(3):214-217

10. Cosyns B, Lochy S, Luchian ML et al (2020) The role of cardiovascular imaging for myocardial injury in hospitalized COVID19 patients. Eur Heart J Cardiovasc Imaging 21(7):709-714. https://doi.org/10.1093/ehjci/jeaa136

11. Beitzke D, Salgado R, Francone M et al (2020a) Cardiac imaging procedures and the COVID-19 pandemic: recommendations of the European Society of Cardiovascular Radiology
(ESCR). Int J Cardiovasc Imaging 36(10):1801-1810. https:// doi.org/10.1007/s10554-020-01892-8

12. Long B, Brady WJ, Koyfman A, Gottlieb M (2020) Cardiovascular complications in COVID-19. Am J Emerg Med 38(7):1504-1507. https://doi.org/10.1016/j.ajem.2020.04.048

13. Nishiga M, Wang DW, Han Y et al (2020) COVID-19 and cardiovascular disease: from basic mechanisms to clinical perspectives. Nat Rev Cardiol 17:543-558. https://doi.org/10.1038/ s41569-020-0413-9

14. Shi S, Qin M, Shen B et al (2020) Association of cardiac injury with mortality in hospitalized patients with COVID-19 in Wuhan, China. JAMA Cardiol 5(7):802-810. https://doi. org/10.1001/jamacardio.2020.0950

15. Huang C, Wang Y, Li X, Ren L, Zhao J, Hu Y, Zhang L, Fan G, Xu J, Gu X, Cheng Z, Yu T, Xia J, Wei Y, Wu W, Xie X, Yin W, Li H, Liu M, Xiao Y, Gao H, Guo L, Xie J, Wang G, Jiang R, Gao Z, Jin Q, Wang J, Cao B (2020) Clinical features of patients infected with 2019 novel coronavirus in Wuhan, China. Lancet 395(10223):497-506. https://doi.org/10.1016/ S0140-6736(20)30183-5. Erratum in: Lancet. 2020 Jan 30

16. Xu H, Hou K, Xu H, Li Z, Chen H, Zhang N, Xu R, Fu H, Sun R, Wen L, Xie L, Liu H, Zhang K, Selvanayagam JB, Fu C, Zhao S, Yang Z, Yang M, Guo Y (2020) Acute myocardial injury of patients with coronavirus disease 2019. medRxiv 2020.03.05.20031591. https://doi. org/10.1101/2020.03.05.20031591

17. Zhou B, She J, Wang Y, Ma X (2020) The clinical characteristics of myocardial injury 1 in severe and very severe patients with 2019 Novel coronavirus disease. J Infect. https://doi. org/10.1016/j.jinf.2020.03.021 (pii: S0163-4453(20)30149-3)

18. Zeng J, Liu Y-X, Yuan J, Wang F-X, Wu W-B, Li J-X, Wang L-F, Gao H, Wang Y, Dong C-F, Li Y-J, Xie X-J, Feng C, Liu L (2020) First case of COVID-19 infection with fulminant myocarditis complication: case report and insights. https://doi. org/10.20944/preprints202003.0180.v1

19. Fang L, Karakiulakis G, Roth M (2020) Are patients with hypertension and diabetes mellitus at increased risk for COVID-19 infection? Lancet Respir Med 8(4):e21. https://doi.org/10.1016/ S2213-2600(20)30116-8

20. Varga Z, Flammer AJ, Steiger P et al (2020) Endothelial cell infection and endotheliitis in COVID-19. Lancet 395(10234):1417-1418. https://doi.org/10.1016/S0140 $-6736(20) 30937-5$

21. Bassareo PP et al (2020) Coronavirus disease 2019, Kawasaki disease, and multisystem inflammatory syndrome in children. $\mathrm{J}$ Pediatr 224:184

22. Chong VH, Chong PL, Metussin D et al (2020) Conduction abnormalities in hydroxychloroquine add on therapy to lopinavir/ritonavir in COVID-19. J Med Virol. https://doi.org/10.1002/jmv.26004

23. Page RL 2nd, O'Bryant CL, Cheng D et al (2016) Drugs that may cause or exacerbate heart failure: a scientific statement from the American Heart Association [published correction appears in Circulation. 2016 Sep 20;134(12):e261]. Circulation 134(6):e32-e69. https://doi.org/10.1161/CIR.0000000000000426

24. Wu Z, McGoogan JM (2020) Characteristics of and important lessons from the coronavirus disease 2019 (COVID-19) outbreak in China: summary of a report of 72314 cases from the Chinese Center for Disease Control and Prevention. JAMA. https://doi. org/10.1001/jama.2020.2648

25. Guo T, Fan Y, Chen M, Wu X, Zhang L, He T, Wang H, Wan J, Wang X, Lu Z (2020) Cardiovascular implications of fatal outcomes of patients with coronavirus disease 2019 (COVID-19). JAMA Cardiol. https://doi.org/10.1001/jamacardio.2020.1017

26. Zhou F, Yu T, Du R, Fan G, Liu Y, Liu Z, Xiang J, Wang Y, Song B, Gu X, Guan L, Wei Y, Li H, Wu X, Xu J, Tu S, Zhang Y, Chen H, Cao B (2020) Clinical course and risk factors for mortality of 
adult inpatients with COVID-19 in Wuhan, China: a retrospective cohort study. Lancet 395(10229):1054-1062. https://doi. org/10.1016/S0140-6736(20)30566-3. Erratum in: Lancet. 2020 Mar28;395(10229):1038. Lancet. 2020 Mar 28;395(10229):1038

27. Madjid M, Miller CC, Zarubaev VV, Marinich IG, Kiselev OI, Lobzin YV, Filippov AE, Casscells SW 3rd (2007) Influenza epidemics and acute respiratory disease activity are associated with a surge in autopsy-confirmed coronary heart disease death: results from 8 years of autopsies in 34,892 subjects. Eur Heart $\mathrm{J}$ 28(10):1205-1210

28. Inciardi RM, Lupi L, Zaccone G, Italia L, Raffo M, Tomasoni D, Cani DS, Cerini M, Farina D, Gavazzi E, Maroldi R, Adamo M, Ammirati E, Sinagra G, Lombardi CM, Metra M (2020) Cardiac involvement in a patient with coronavirus disease 2019 (COVID-19). JAMA Cardiol. https://doi.org/10.1001/jamacardio .2020 .1096

29. Chen C, Zhou Y, Wang DW (2020) SARS-CoV-2: a potential novel etiology of fulminant myocarditis. Herz. https://doi. org/10.1007/s00059-020-04909-Z

30. Xie X, Zhong Z, Zhao W, Zheng C, Wang F, Liu J (2020) Chest CT for typical 2019-nCoV pneumonia: relationship to negative RT-PCR testing. Radiology. https://doi.org/10.1148/radiol.20202 00343

31. Ng MY, Lee EYP, Yang J, Yang F, Li X, Wang H, Lui MM, Lo CSY, Leung B, Khong PL, Hui CKM, Yuen KY, Kuo MD (2020) Imaging profile of the COVID-19 infection: radiologic findings and literature review. Radiol Cardiothorac Imaging 2(1):e200034. https://doi.org/10.1148/ryct.2020200034

32. ACR recommendations for the use of chest radiography and computed tomography (CT) for suspected COVID-19 infection. https ://www.acr.org/Advocacy-and-Economics/ACR-Position-State ments/Recommendations-for-Chest-Radiography-and-CT-forSuspected-COVID19-Infection, Accessed 16th Mar 2020

33. Beitzke D, Salgado R, Francone $M$ et al (2020b) Cardiac imaging procedures and the COVID-19 pandemic: recommendations of the European Society of Cardiovascular Radiology (ESCR). Int J Cardiovasc Imaging 36(10):1801-1810. https://doi.org/10.1007/ s10554-020-01892-8

34. Allen BD, Wong TC, Bucciarelli-Ducci C et al (2020) Society for Cardiovascular Magnetic Resonance (SCMR) guidance for re-activation of cardiovascular magnetic resonance practice after peak phase of the COVID-19 pandemic. J Cardiovasc Magn Reson 22:58. https://doi.org/10.1186/s12968-020-00654-8

35. Richardson P, McKenna W, Bristow M, Maisch B, Mautner B, O'Connell J, Olsen E, Thiene G, Goodwin J, Gyarfas I, Martin I, Nordet P (1996) Report of the 1995 World Health Organization/ International Society and Federation of Cardiology Task Force on the Definition and Classification of cardiomyopathies. Circulation 93(5):841-842

36. Xu Z, Shi L, Wang Y, Zhang J, Huang L, Zhang C, Liu S, Zhao P, Liu H, Zhu L, Tai Y, Bai C, Gao T, Song J, Xia P, Dong J, Zhao J, Wang FS (2020) Pathological findings of COVID-19 associated with acute respiratory distress syndrome. Lancet Respir Med 8(4):420-422. https://doi.org/10.1016/S2213-2600(20)30076-X. Erratum in: Lancet Respir Med. 2020 Feb 25

37. Ding Y, Wang H, Shen H, Li Z, Geng J, Han H, Cai J, Li X, Kang W, Weng D, Lu Y, Wu D, He L, Yao K (2003) The clinical pathology of severe acute respiratory syndrome (SARS): a report from China. J Pathol 200(3):282-289

38. Ng DL, Al Hosani F, Keating MK, Gerber SI, Jones TL, Metcalfe MG, Tong S, Tao Y, Alami NN, Haynes LM, Mutei MA, Abdel-Wareth L, Uyeki TM, Swerdlow DL, Barakat M, Zaki SR (2016) Clinicopathologic, immunohistochemical, and ultrastructural findings of a fatal case of Middle East respiratory syndrome coronavirus infection in the United Arab Emirates, April 2014.
Am J Pathol 186(3):652-658. https://doi.org/10.1016/j.ajpat h.2015.10.024

39. Caforio AL, Pankuweit S, Arbustini E, Basso C, Gimeno-Blanes J, Felix SB, Fu M, Heliö T, Heymans S, Jahns R, Klingel K, Linhart A, Maisch B, McKenna W, Mogensen J, Pinto YM, Ristic A, Schultheiss HP, Seggewiss H, Tavazzi L, Thiene G, Yilmaz A, Charron P, Elliott PM, European Society of Cardiology Working Group on Myocardial and Pericardial Diseases (2013) Current state of knowledge on aetiology, diagnosis, management, and therapy of myocarditis: a position statement of the European Society of Cardiology Working Group on Myocardial and Pericardial Diseases. Eur Heart J 34(33):2636-2648, 2648a-2648d. https:// doi.org/10.1093/eurheartj/eht210

40. Ponikowski P, Voors AA, Anker SD, Bueno H, Cleland JGF, Coats AJS, Falk V, González-Juanatey JR, Harjola V-P, Jankowska EA, Jessup M, Linde C, Nihoyannopoulos P, Parissis JT, Pieske B, Riley JP, Rosano GMC, Ruilope LM, Ruschitzka F, Rutten FH, van der Meer P, ESC Scientific Document Group (2016) 2016 ESC Guidelines for the diagnosis and treatment of acute and chronic heart failure: the Task Force for the diagnosis and treatment of acute and chronic heart failure of the European Society of Cardiology (ESC) Developed with the special contribution of the Heart Failure Association (HFA) of the ESC. Eur Heart J 37(27):2129-2200. https://doi.org/10.1093/eurheartj/ehw128

41. Kindermann I, Barth C, Mahfoud F, Ukena C, Lenski M, Yilmaz A, Klingel K, Kandolf R, Sechtem U, Cooper LT, Böhm M (2012) Update on myocarditis. J Am Coll Cardiol 59(9):779-792. https ://doi.org/10.1016/j.jacc.2011.09.074

42. Yilmaz A, Klingel K, Kandolf R, Sechtem U (2009) Imaging in inflammatory heart disease: from the past to current clinical practice. Hell J Cardiol 50(6):449-460

43. Lee SP, Im HJ, Kang S, Chung SJ, Cho YS, Kang H, Park HS, Hwang DW, Park JB, Paeng JC, Cheon GJ, Lee YS, Jeong JM, Kim YJ (2017) Noninvasive imaging of myocardial inflammation in myocarditis using 68Ga-tagged mannosylated human serum albumin positron emission tomography. Theranostics 7(2):413424. https://doi.org/10.7150/thno. 15712

44. Tschöpe C, Cooper LT, Torre-Amione G, Van Linthout S (2019) Management of myocarditis-related cardiomyopathy in adults. Circ Res 124(11):1568-1583. https://doi.org/10.1161/CIRCR ESAHA.118.313578

45. Cau R, Bassareo P, Saba L (2020) Cardiac involvement in COVID19-assessment with echocardiography and cardiac magnetic resonance imaging. SN Compr Clin Med. https://doi.org/10.1007/ s42399-020-00344-7

46. Suri JS, Puvvula A, Biswas M et al (2020) COVID-19 pathways for brain and heart injury in comorbidity patients: a role of medical imaging and artificial intelligence-based COVID severity classification: a review. Comput Biol Med 124:103960. https://doi. org/10.1016/j.compbiomed.2020.103960

47. Abdel-Aty H, Boyé P, Zagrosek A, Wassmuth R, Kumar A, Messroghli D, Bock P, Dietz R, Friedrich MG, Schulz-Menger J (2005) Diagnostic performance of cardiovascular magnetic resonance in patients with suspected acute myocarditis: comparison of different approaches. J Am Coll Cardiol 45(11):1815-1822

48. Friedrich MG, Sechtem U, Schulz-Menger J, Holmvang G, Alakija P, Cooper LT, White JA, Abdel-Aty H, Gutberlet M, Prasad S, Aletras A, Laissy JP, Paterson I, Filipchuk NG, Kumar A, Pauschinger M, Liu P, International Consensus Group on Cardiovascular Magnetic Resonance in Myocarditis (2009) Cardiovascular magnetic resonance in myocarditis: a JACC White Paper. J Am Coll Cardiol 53(17):1475-1487. https://doi.org/10.1016/j. jacc.2009.02.007

49. Gutberlet M, Thiele H (2010) Comment on: Jeserich M, Konstantinides S, Pavlik G, Bode C, Geibel A (2009) Non-invasive imaging in the diagnosis of acute viral myocarditis. Clin Res 
Cardiol 98:753-763. Clin Res Cardiol 99(4):261-263; author reply 265-266. https://doi.org/10.1007/s00392-010-0132-z

50. Krishnamoorthy P, Croft LB, Ro R et al (2020) Biventricular strain by speckle tracking echocardiography in COVID-19: findings and possible prognostic implications. Future Cardiol. https ://doi.org/10.2217/fca-2020-0100

51. Spagnolo P, Balestro E, Aliberti S et al (2020) Pulmonary fibrosis secondary to COVID-19: a call to arms? Lancet Respir Med 8(8):750-752. https://doi.org/10.1016/S2213-2600(20)30222-8

52. Kalisz Kevin, Rajiah Prabhakar (2017) Computed tomography of cardiomyopathies. Cardiovasc Diagn Ther 7(5):539-556. https:// doi.org/10.21037/cdt.2017.09.07

53. Sun Y, Ma P, Bax JJ, Blom N, Yu Y, Wang Y, Han X, Wang Y, Van Der Wall EE (2003) 99mTc-MIBI myocardial perfusion imaging in myocarditis. Nucl Med Commun 24(7):779-783

54. Skali H, Murthy VL, Al-Mallah MH et al (2020) Guidance and best practices for nuclear cardiology laboratories during the coronavirus disease 2019 (COVID-19) pandemic: an information statement from ASNC and SNMMI 2020. J Nucl Med 61:784-791

55. Dambrin G, Wartski M, Toussaint M, Ghostine S, Caussin C, Angel C, Lancelin B, Paul JF (2004) Anomalies in myocardial contrast uptake revealed by multislice cardiac CT during acute myocarditis. Arch Mal Coeur Vaiss 97(10):1031-1034 (French)

56. Brett NJ, Strugnell WE, Slaughter RE (2011) Acute myocarditis demonstrated on CT coronary angiography with MRI correlation. Circ Cardiovasc Imaging 4(3):e5-e6. https://doi.org/10.1161/ CIRCIMAGING.110.957779

57. Boussel L, Gamondes D, Staat P, Elicker BM, Revel D, Douek P (2008) Acute chest pain with normal coronary angiogram: role of contrast-enhanced multidetector computed tomography in the differential diagnosis between myocarditis and myocardial infarction. J Comput Assist Tomogr 32(2):228-232. https://doi.org/10.1097/ RCT.0b013e3181452199

58. Redheuil AB, Azarine A, Garrigoux P, Mousseaux E (2006) Images in cardiovascular medicine. Correspondence between delayed enhancement patterns in multislice computed tomography and magnetic resonance imaging in a case of acute myocarditis. Circulation 114(19):e571-e572

59. Pontone G, Baggiano A, Conte E et al (2020) "Quadruple RuleOut" with computed tomography in a COVID-19 patient with equivocal acute coronary syndrome presentation. JACC Cardiovasc Imaging 13(8):1854-1856. https://doi.org/10.1016/j. jcmg.2020.04.012

60. Collet J-P, Thiele H, Barbato E, Barthélémy O, Bauersachs J, Bhatt DL, Dendale P, Dorobantu M, Edvardsen T, Folliguet T, Gale CP, Gilard M, Jobs A, Jüni P, Lambrinou E, Lewis BS, Mehilli J, Meliga E, Merkely B, Mueller C, Roffi M, Rutten FH, Sibbing D, Siontis GCM, ESC Scientific Document Group (2020) 2020 ESC Guidelines for the management of acute coronary syndromes in patients presenting without persistent ST-segment elevation: the Task Force for the management of acute coronary syndromes in patients presenting without persistent ST-segment elevation of the European Society of Cardiology (ESC). Eur Heart J. https://doi.org/10.1093/eurheartj/ehaa575

61. Saba L, Biswas M, Kuppili V et al (2019) The present and future of deep learning in radiology. Eur J Radiol 114:14-24. https://doi. org/10.1016/j.ejrad.2019.02.038

62. Eisenberg MJ, Dunn MM, Kanth N, Gamsu G, Schiller NB (1993) Diagnostic value of chest radiography for pericardial effusion. $\mathrm{J}$ Am Coll Cardiol 22(2):588-593

63. Brakohiapa EKK, Botwe BO, Sarkodie BD, Ofori EK, Coleman J (2017) Radiographic determination of cardiomegaly using cardiothoracic ratio and transverse cardiac diameter: can one size fit all? Part one. Pan Afr Med J 27:201. https://doi.org/10.11604/ pamj.2017.27.201.12017
64. ACR recommendations for the use of chest radiography and computed tomography (CT) for suspected COVID-19 infection. https ://www.acr.org/Advocacy-and-Economics/ACR-Position-State ments/Recommendations-for-Chest-Radiography-and-CT-forSuspected-COVID19-Infection. Accessed 23rd June 2020

65. Bandirali M, Sconfienza LM, Serra R et al (2020) Chest x-ray findings in asymptomatic and minimally symptomatic quarantined patients in Codogno Italy. Radiology 295:E7

66. Guagliumi G, Sonzogni A, Pescetelli I, Pellegrini D, Finn AV (2020) Microthrombi and ST-segment-elevation myocardial infarction in COVID-19. Circulation 142(8):804-809. https:// doi.org/10.1161/CIRCULATIONAHA.120.049294

67. Maiese A, Manetti AC, La Russa R et al (2020) Autopsy findings in COVID-19-related deaths: a literature review. Forensic Sci Med Pathol. https://doi.org/10.1007/s12024-020-00310-8

68. Manolis AS, Manolis TA, Manolis AA, Papatheou D, Melita H (2020) COVID-19 infection: viral macro- and micro-vascular coagulopathy and thromboembolism/prophylactic and therapeutic management. J Cardiovasc Pharmacol Ther. https://doi. org/10.1177/1074248420958973

69. Pasupathy S, Air T, Dreyer RP, Tavella R, Beltrame JF (2015) Systematic review of patients presenting with suspected myocardial infarction and nonobstructive coronary arteries. Circulation 131:861-870

70. Grün S, Schumm J, Greulich S, Wagner A, Schneider S, Bruder O, Kispert EM, Hill S, Ong P, Klingel K, Kandolf R, Sechtem U, Mahrholdt H (2012) Long-term follow-up of biopsy-proven viral myocarditis: predictors of mortality and incomplete recovery. J Am Coll Cardiol 59(18):1604-1615. https://doi.org/10.1016/j. jacc.2012.01.007

71. Schumm J, Greulich S, Wagner A, Grün S, Ong P, Bentz K, Klingel K, Kandolf R, Bruder O, Schneider S, Sechtem U, Mahrholdt $\mathrm{H}$ (2014) Cardiovascular magnetic resonance risk stratification in patients with clinically suspected myocarditis. J Cardiovasc Magn Reson 16:14. https://doi.org/10.1186/1532-429X-16-14

72. Pan JA, Lee YJ, Salerno M (2018) Diagnostic performance of extracellular volume, native T1, and T2 mapping versus Lake Louise criteria by cardiac magnetic resonance for detection of acute myocarditis: a meta-analysis. Circ Cardiovasc Imaging 11(7):e007598. https://doi.org/10.1161/CIRCIMAGIN G.118.007598

73. Cau R, Bassareo P, Cherchi V et al (2020) Early diagnosis of chemotherapy-induced cardiotoxicity by cardiac MRI. Eur J Radiol 130:109158. https://doi.org/10.1016/j.ejrad.2020.109158

74. Puntmann VO, Carerj ML, Wieters I et al (2020) Outcomes of cardiovascular magnetic resonance imaging in patients recently recovered from coronavirus disease 2019 (COVID-19). JAMA Cardiol. https://doi.org/10.1001/jamacardio.2020.3557

75. Leslie K, Blay R, Haisch C, Lodge A, Weller A, Huber S (1989) Clinical and experimental aspects of viral myocarditis. Clin Microbiol Rev 2(2):191-203. https://doi.org/10.1128/cmr.2.2.191

76. Peretto G, Sala S, Rizzo S et al (2020) Ventricular arrhythmias in myocarditis: characterization and relationships with myocardial inflammation. J Am Coll Cardiol 75(9):1046-1057. https://doi. org/10.1016/j.jacc.2020.01.036

77. Chang JJ, Lin MS, Chen TH et al (2017) Heart failure and mortality of adult survivors from acute myocarditis requiring intensive care treatment - a nationwide cohort study. Int J Med Sci 14(12):1241-1250. https://doi.org/10.7150/ijms.20618

78. Mitrani RD, Dabas N, Goldberger JJ (2020) COVID-19 cardiac injury: implications for long-term surveillance and outcomes in survivors. Heart Rhythm. https://doi.org/10.1016/j.hrthm .2020 .06 .026

79. Han Y, Chen T, Bryant J, Bucciarelli-Ducci C, Dyke C, Elliott MD, Ferrari VA, Friedrich MG, Lawton C, Manning WJ et al (2020) Society for Cardiovascular Magnetic Resonance (SCMR) 
guidance for the practice of cardiovascular magnetic resonance during the COVID-19 pandemic. J Cardiovasc Magn Reson 22(1):26

80. Salah HM, Naser JA, Calcaterra G, Bassareo PP, Mehta JL (2020) The effect of anticoagulation use on mortality in COVID-19 infection. Am J Cardiol. https://doi.org/10.1016/j.amjcard.2020.08.005

81. Spagnolo P, Balestra E, Aliberti S, Cocconcelli E, Biondini D, Della Casa G, Sverzellati N, Maher TM (2020) Pulmonary fibrosis secondary to COVID-19: a call to arms? Lancer Respir Med 8(8):750-752

Publisher's Note Springer Nature remains neutral with regard to jurisdictional claims in published maps and institutional affiliations. 